UDC 811.111'37'373:[646:7.017.4]]=111

DOI https://doi.org/10.32841/2409-1154.2020.45-2.30

\author{
Pidrushniak K. V., \\ Lecturer at the English Language Department \\ Philology Institute \\ of Petro Mohyla Black Sea National University
}

\title{
THE STRUCTURE OF THE LEXICAL-SEMANTIC FIELD "COLOUR" IN THE DOMAIN OF CLOTHES
}

Summary. Modern linguistic researches are dedicated to the study of color names. Investigators have conducted a thorough research of color names, made a great contribution to the evolution of this phenomenon in linguistics, in the development of the problems of the lexical-semantic field "color". Linguistics of color, which has its own theoretical and methodological basis, analyzing the problem of studying color names, has gained some experience in the study of symbolism and semantics of color and its shades.

The article focuses on the description of the lexical-semantic field "color" by means of studying the features of the English color names in the domain of clothes. On the basis of color names, their specifics are closely viewed and the structure of the lexical-semantic field "color" in the domain of clothes is created.

The author emphasizes that color names play an important role in the formation of the linguistic picture of the world, because different linguistic and cultural communities have certain associations with each color. Identifying the lexicalsemantic features of color and its symbolism plays an important role in determining the national and cultural specifics of language. The semantic diversity of color symbolism is closely related to psychological perception and has numerous intercultural differences in relation to phenomena and events in people's lives.

A large number of color names under the analysis are the source of numerous associations that make them elements of a figurative structure of objects. The results show that some of the non-standard color attributes derive from the names of plants, animals, minerals and fossil. Their color is poorly correlated with the reference color, it is not always steady and the same in different copies, but it is well known to every native speaker. That is, without thinking, everyone will say red about tomato, red about strawberries, burgundy about pomegranate. These color names are depicted on clothing as we see them in nature (in relation to color).

Key words: color names, lexical-semantic field "color", nuclear zone, central zone, peripheral zone, structure of the lexical-semantic field "color".

Introduction. Over the last decade, researchers have become increasingly interested in the study of color names. Numerous researchers have addressed this study since the 19th century. H. Herne, M. Sourovtseva, L. Granovska, N. Pelevina, B. Berlin, P. Kay conducted a thorough investigation of color names and made a great contribution to the development of this phenomenon in Linguistics, in the development of the problems of the lexicalsemantic field "color" [5, p. 4]. H. Herne studied Slavic lexemes on the color designations. M. Surovtseva and L. Granovsky researched the history of color names. B. Berlin and P. Kay studied the etymology of color [4, p. 246]. V. Moskovich, V. Makeenko,
V. Yurik, N. Pelevina investigated the semantic field of color names [2, p. 199].

Scientists confirm that the lexical-semantic field has its structure, but there are several views on this issue. The most convincing is the approach of A. Ufimtseva, who believes that the structure of the lexical-semantic field consists of the nuclear, central and peripheral zones. The nuclear of the field is represented by a common sem, which organizes the semantic field deployment around it. The central zone consists of units that have an integral, a common differential value with the nuclear, and the peripheral zone includes units that are most semantically distant from the nuclear [3, p. 139].

Using V. Ivarovskaya's classification of color names, according to which she identifies ten primary colors: white, red, blue, green, yellow, brown, gray, black, orange, purple, we divide the removed color names by categories of primary colors. The reason for choosing this classification is that the classification is based on the principle of division by lexical-semantic field: all these colors have the ability to be part of color fields in the form of their nucleus [1, p. 104].

However, even though many studies have reported the definition of the features of the lexical-semantic field «color», which are determined by a certain sphere of color use, there has been very little research of the definition of the functioning specificity of color names in the domain of clothes which is needed to be considered in detail. The scientific novelty of the research is the deepening of the description of the lexical-semantic field "color" in English by studying the peculiarities of the functioning of color names in the field of clothing.

The paper focuses on the description of the lexical-semantic field "color" by means of studying the features of the English color names functioning in the field of clothing. The purpose of the present study is, therefore, to identify the features of the lexical-semantic field "color" in the domain of clothes. The study investigates features and specifics of color names and created the structure of the lexical-semantic field "color". Specifically, the article examines the question of studying color names in linguistics, the essence of the concept of "lexical-semantic field", the structure of the lexical-semantic field "color" that is constructed on the basis of the removed color names.

Methods. The research methods, which are used in the process of identifying and describing specific features of colour names, are descriptive-analytical, elements of component analysis, elements of comparative and quantitative analysis.

This research focuses on about 400 articles of women's clothing and 350 men's clothing items on the basis of English online stores. In total, 57 English color items of women's and 43 color attributes 
of men's clothes are studied. Therefore, the sampling method was used to select the actual material of the study.

As the material of the analysis shows, according to the meanings of these color names in dictionaries, the accents on the shades can be changed. That is, the shades of some colors names sometimes do not match their definitions of the dictionary. During the research at the stage of assigning color to the microfield, a visual image (the shade that is depicted on the pages of American and British online stores) is taken into consideration.

Results. On the basis of the English color names of the women's and men's clothing, their specifics are closely viewed and the structure of the lexical-semantic field color is built.

The problem of understanding some colors is determined by the national-cultural specifics, which is expressed by intercultural differences between certain phenomena in different cultures, therefore, studying their specifics requires accessing the Internet resource for additional information.

According to the theory of A.A. Ufimtseva, the nuclear, central and peripheral zones are distinguished in the lexical-semantic field color where 10 nuclear lexical units are identified: white, red, blue, green, yellow, brown, black, orange, purple, grey. Thus, the lexicalsemantic field color is presented in 10 microfields. In the study of color names, it is noticed that there are differences between their use in relation to men's and women's clothing. Therefore, one of the criteria for the analysis is the division of the color units denoting women's and men's clothes, according to which the fields for women's and men's clothes are structured respectively.

Consider the lexical-semantic microfield white with the nucleus white. The center of the lexical-semantic field on the material of men's clothing is color name cream, which can be attributed to both microfields whit and yellow according to the dictionary meaning, but in the context of online stores, which make up the research material, it clearly expresses white. In the field of women's clothing, the center of the microfield whit is not represented. The periphery of men's clothing includes Carl's stone, chino, naked, while natural and chalk are referred to the periphery of women's clothing. These units are the furthest from the nucleus and their belonging to white is either contextually determined or requires additional culturally labeled knowledge.

The center of the lexical-semantic microfield red with the nucleus red on the material of men's clothing are such units as scarlet, raspberry. Elements of the periphery are rouge, pomegranate, milkshake, zephyr, pink willow, salmon heather, rose dew. The center of the field of women's clothing consists of coral, maroon, magenta, terra cotta, pink blush, tomato, strawberry, paprika, cinnamon, plum, brilliant fuchsia, exotic ruby, potpourri pink, sunrise pink, neon flamingo. Peripheral units are rust, rosehip, petunia, raspberry punch, wine, candy, spring, summer azalea. However, according to the dictionary, the original name rust refers to the brown color, but the item of clothing on the material of the online store is expressed in red.

The center of the microfield blue with the nucleus blue on the material of men's units includes such color names as cornflower and deep cobalt. Peripheral elements are lagoon, silver pine, new green tea, tourmaline, fall royal. The center of the lexical-semantic microfield of female units includes perfect turquoise, ultramarine, true indigo, elysian blue, navy. Peripheral elements are quince, fantasy aqua, East Side royal, Aruba, galaxy, sail, dark night, marine, because these color names are not recorded in the dictionary as certain shades of color.
Next is the lexical-semantic microfield green with the nucleus green. The center of the field on the material of men's clothing is olive, and women's clothing is avocado, emerald, which are often used to depict clothing. The periphery of men's clothing includes desert cactus, sycamore, and the categories black moss, tropical, admiral are referred to women's clothing, because these units are semantically furthest from the nucleus: the semantic component of color is not fixed in dictionary entries or in general cultural practice.

The center of the lexical-semantic microfield yellow with the nucleus yellow on the material of women's clothing are such units as lemon, apricot. There are no units in the center of men's clothing. Elements of the periphery to indicate the color of women's clothing are wheat, and men's clothing - hot mess. Their affiliation to the microfield "yellow" is ambiguous and requires some cultural background.

The center of the lexical-semantic microfield brown with the nucleus brown on the material of men's clothing includes such units as iconic khaki, sand, coastal beige, classic camel. The periphery includes tobacco, bungee cord. The center of the lexical-semantic microfield "brown" to denote women's clothing includes light ivory. Peripheral elements are gravel, oatmeal heather, latte, Madison tan.

Consider the lexical-semantic microfield grey with the nucleus grey. Units such as metallic, dove, antique pewter are the center of the lexical-semantic microfield on the material of men's clothing, and charcoal is referred to the center of women's clothing. The peripheral zone of this microfield of men's clothing includes steel, granite, ironstone, pavement, new shadow, while the expanded threecomponent designations new heather gray, urban gray jungle constitute the periphery of the corresponding microfield in the field of women's clothing. Color semantics in them has an associative character.

The next step in the study is the microfield black. Unusual colors of the microfield black are used to characterize men's clothing and these two units obsidian and moonless night are related to the periphery.

The same situation is with the lexical-semantic microfield orange. Such colors as Lady Danger, shell peach (women's clothing), and Fire Rooster, persimmon (men's clothing) are peripheral.

Consider the last removed color names of the lexical-semantic microfield violet. The central unit, used to denote women's clothing, is eggplant, while dusty mauve is the central unit of men's clothing.

The meanings of all color names are checked by dictionaries during their division into central and peripheral zones. Color names, which are recorded in the dictionary as certain shades of color or dictionary articles which contain a mention of a particular color, are attributed to the center.

It was examined that one of the most important features of the field is its structural organization, which is determined by the delineation of the nuclear, central and peripheral zones. After creating the structure of the lexical-semantic field, it was concluded that the peripheral elements of this field predominate over the nuclear and central and are characterized by the lowest frequency of use and stylistic color value. The central zone includes the most commonly used words with bright integral values and have a common differential with the nuclear. The structure has many gaps in the "Center" category, probably due to the fact that these elements are characterized by a low frequency of use in the domain of clothes.

Discussion. The results show that the central zone includes the most commonly used words with bright integral values and has a common differential with the nuclear. The structure has many gaps in the "Center" category, probably due to the fact that these 
elements are characterized by a low frequency of use in the domain of clothes.

It should be noted that the largest number of selected English colors are part of the microfield red, its color names are expressed by many shades: coral, pink, burgundy, etc. The lexical-semantic microfield violet has the least developed structure because purple is a combination of red and blue, which the largest number of elements belongs to in this study. The structure of the lexical-semantic field color has 3 gaps in the category Center in the domain of men's and women's clothing, because these elements have a low frequency of use. The category "Periphery" of women's clothing is not represented in two microfields (black and violet), whereas among the items of men's clothes peripheral elements are not only in one microfield (violet). The center of men's clothing includes smaller amount of colour names - 14 elements, the center of the lexical-semantic field of female units -27 . The structure has almost the same number of peripheral units: 29 elements of men's clothes and 30 women's items.

Conclusions. A large number of color names under the analysis are the source of numerous associations that make them elements of a figurative structure of objects. Some of the non-standard color attributes derive from the names of plants, animals, minerals, fossil, etc. In terms of grammar they are expressed by nouns or noun phrases (which is a characteristic feature of word formation in English) or combinations of nouns with adjectives.

Based on the results of the analysis it is concluded that the peripheral elements of this field dominate over the nuclear and central ones in the research, but they are characterized by the least frequent usage and stylistic color value. The central zone includes the most commonly used words with bright integral values. The structure has many gaps in the central zone, assumingly because these elements are characterized by a low frequency of usage.

During the analysis, it is investigated that a certain number of colour names is at the verge of two microfields. An example of this is the color names, which are depicted in turquoise, so they are located at the intersection of the microfields "blue" and "green". Due to the limited amount of work on this issue, enough attention has not been given, which can be described as a prospect of further research.

\section{References:}

1. Иваровская В.И. Лексическое значение цветовых прилагательных в синагматико-парадигматическом и словообразовательном аспектах. Вестник СПбГУ, сер. 2. 1998. С. 104-109.

2. Левко О. Лексико-семантичне поле «Природні явища» в давньогрецькій мові. Studia linguistica. 2014. № 8. С. 199-203. URL : nbuv. gov.ua/UJRN/Stling_2014_8_34.

3. Уфимцева А.А. Опыт изучения лексики как системы (на материале английского языка). Москва, 1962. 287 с.
4. Berlin B., Kay P. Basic Colour Terms: Their Universality and Evolution. Linguistic Society of America. University of California Press, 1973. Vol. 49, No. 1. P. 245-248. DOI: https://doi.org/10.2307/412128.

5. Levinson, Stephen C. Yélî Dnye and the Theory of Basic Color Terms. Sonia Das: Journal of Linguistic Anthropology. 2000. No. 10.1. P. 3-55. DOI: https://doi.org/10.1525/jlin.2000.10.1.3.

Підрушняк К. В. Структура лексико-семантичного поля «колір» у сфері одягу

Анотація. Сучасні лінгвістичні наукові роботи присвячені вивченню кольоронайменувань. Науковці провели ретельне дослідження кольоропозначень, зробили великий внесок в еволюцію цього явища в лінгвістиці, в розробку проблем лексико-семантичного поля «колір». Лінгвістика кольору, що має власну теоретичну і методологічну базу, займаючись аналізом проблеми вивчення кольоропозначення і найменувань кольорів, накопичила певний досвід в дослідженні символіки і семантики кольору і його відтінків.

Стаття присвячена опису лексико-семантичного поля «колір» шляхом вивчення особливостей англійських кольоронайменувань у сфері одягу. На основі кольоропозначень уважно розглядається їх специфіка та будується структура лексико-семантичного поля «колір» у галузі одягу.

Автор наголошує на тому, що кольоронайменування відіграють неабияку роль у формуванні мовної картини світу, оскільки з кожним кольором у різних лінгвокультурних спільнот пов'язані певні асоціації. Виявлення лексико-семантичних особливостей кольоронайменування i його символізму грає важливу роль у визначенні національно-культурної специфіки мовних засобів. Семантична багатоплановість символізму кольоропозначення тісно пов'язана із психологічним сприйняттям і має численні міжкультурні відмінності у відношенні до явищ і подій у житті людей.

Велика кількість аналізованих кольоронайменувань $\epsilon$ джерелом численних асоціацій, що роблять їх елементами образної структури предметів. Отримані результати свідчать про те, що деякі нестандартні кольоропозначення походять від назв рослин, тварин, мінералів та копалин. Їхній колір погано співвідноситься з еталонним, він не завжди рівномірний і однаковий у різних екземплярах, але він добре відомий кожному носію мови. Тобто, не замислюючись, кожна людина скаже червоний про томат, червоний про полуницю, бордовий про гранат. Дані кольоронайменування на одязі зображені так, як ми бачимо їх у природі (стосовно кольору).

Ключові слова: кольоронайменування, лексико-семантичне поле «колір», ядерна зона, центральна зона, периферійна зона, структура лексико-семантичного поля «колір». 